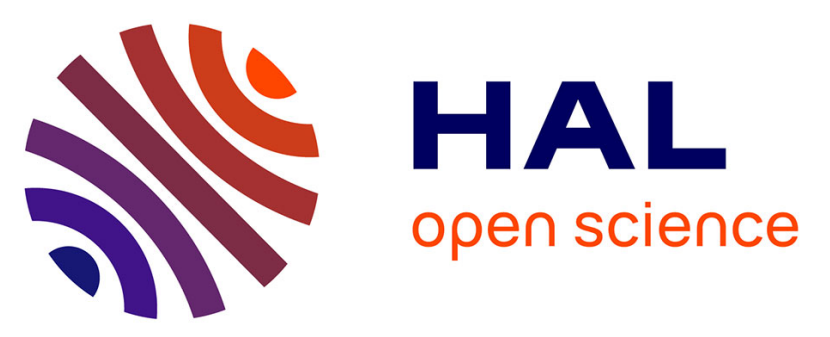

\title{
Transpiration, growth and latex production of a Hevea brasiliensis stand facing drought in Northeast Thailand : the use of the WaNuLCAS model as an exploratory tool
}

Laurie Boithias, Frederic C. Do, Supat Isarangkool Na Ayutthaya, Junyia Junjittakarn, S. Siltecho, Claude Hammecker

\section{To cite this version:}

Laurie Boithias, Frederic C. Do, Supat Isarangkool Na Ayutthaya, Junyia Junjittakarn, S. Siltecho, et al.. Transpiration, growth and latex production of a Hevea brasiliensis stand facing drought in Northeast Thailand: the use of the WaNuLCAS model as an exploratory tool. Experimental Agriculture, 2012, 48 (1), pp.49-63. 10.1017/S001447971100086X . ird-00653618

\section{HAL Id: ird-00653618 \\ https://hal.ird.fr/ird-00653618}

Submitted on 9 Jan 2012

HAL is a multi-disciplinary open access archive for the deposit and dissemination of scientific research documents, whether they are published or not. The documents may come from teaching and research institutions in France or abroad, or from public or private research centers.
L'archive ouverte pluridisciplinaire HAL, est destinée au dépôt et à la diffusion de documents scientifiques de niveau recherche, publiés ou non, émanant des établissements d'enseignement et de recherche français ou étrangers, des laboratoires publics ou privés. 
MODELING DROUGHT IMPACT ON H. BRASILIENSIS

TRANSPIRATION, GROWTH AND LATEX PRODUCTION OF A HEVEA BRASILIENSIS STAND FACING DROUGHT IN

NORTHEAST THAILAND: THE USE OF THE WANULCAS MODEL

By L. Boithias ${ }^{\mathrm{a}, 1}$, F.C. Do ${ }^{\mathrm{b}}$, S. Isarangkool Na Ayutthaya ${ }^{\mathrm{c}}$, J. Junjittakarn ${ }^{\mathrm{c}}$, S. Siltecho ${ }^{\mathrm{d}}$ and C. Hammecker ${ }^{\mathrm{e}}$

${ }^{\mathrm{b}}$ IRD, UMR Eco\&Sols, Campus SupAgro-INRA, Montpellier, France, and

${ }^{\mathrm{c}}$ Faculty of Agriculture, Khon Kaen University, Khon Kaen, Thailand, and

${ }^{\mathrm{d}}$ Land Development Department, region five, Khon Kaen, Thailand, and 


\section{SUMMARY}

16 To benefit from the growing world demand for natural rubber, Hevea brasiliensis is increasingly planted in drought prone areas, such as in the southern part of northeast

18 Thailand. Modelling can be a useful approach in identifying key points of improvement for rubber tree cultivation in such water-limited areas. The first objective of this study

20 was to test the possibility of using the WaNuLCAS model as an exploratory tool to simulate water-use, growth and latex production in a pure stand on a daily basis. The

22 second was to evaluate the relative accuracy of predictions with the current model version. Finally, the third aim of this study was to identify particular parameterizations

24 which may be adapted to improve overall prediction quality.

Model outputs were compared to measurements recorded in a mature rubber tree 26 stand of RRIM 600 clones growing in the water-limited area of northeast Thailand. The period of analysis concerned seven months of full foliation, from May to November,

28 including a severe drought spell. Whole-tree transpiration was estimated by xylem sap flow measurement from eleven trees. The results show that the model was able to

30 simulate daily and seasonal change of soil water content, tree transpiration, girth increment and latex production within plausible ranges. However, under detailed

32 scrutiny, the predictions show large inaccuracies compared to the observations: soil water content $\left(R^{2}=0.461, R M S E_{\text {rel }}=35 \%\right)$, tree transpiration $\left(R^{2}=0.104, R M S E_{\text {rel }}=94 \%\right)$,

34 tree girth increment $\left(R^{2}=0.916, R M S E_{\text {rel }}=208 \%\right)$ and latex production $\left(R^{2}=0.423\right.$, $\left.R M S E_{\text {rel }}=169 \%\right)$. As soil water content was overestimated during the driest periods, no 36 water stress was predicted and transpiration, growth and latex production were logically 
overestimated during such periods. However, tree transpiration was also largely

38 overestimated in conditions of non-limiting soil water availability with high evaporative demand. Hence, two key points of parameterization and improvement are identified for

40 better simulation in our conditions: the soil water balance and particularly the ratio between water infiltration and run-off; and the regulation of transpiration under high

42 evaporative demand. In conclusion, WaNuLCAS model is usable as an exploratory model to simulate water use, growth and production for a pure rubber tree stand. However, in

44 our conditions of much degraded soil and high evaporative demand, the modules of soil water balance and tree transpiration require particular parameterizations and 46 improvement.

\section{INTRODUCTION}

48 As a consequence of increasing demand for natural rubber and competition with oil palm in the traditional areas, the extension of Hevea brasiliensis cultivation is accelerating in

50 drought-prone areas, such as in the southern part of northeast Thailand. Although growth and latex production are two distinct physiological phenomena in rubber trees (Rao et al.,

52 1998), they are both strongly related to evaporative demand and water availability. The importance of the water relations for latex production is known (Pakianathan et al.,

54 1989), and some authors have studied the impact of water constraints on tree water status, girth increment and latex production (Rao et al., 1990; Chandrashekar et al., 1998). Water

56 stress generally results from an imbalance between transpiration, driven by evaporative demand, and root-water-uptake allowed by soil water availability. Drought stress occurs 58 whenever soil water availability drops below a certain threshold, thus inducing 
restrictions to transpiration and growth. Frequently, but not invariably, soil dryness is

60 coupled with strong evaporation caused by air dryness. Conversely, an atmospheric drought may occur despite water being available in the soil. A model that predicts tree

62 water use, tree growth and latex production model can be a useful tool to analyze key points of improvement in rubber tree cultivation in water-limited areas. Growth models

64 have become a tool for making rational land use decisions and for monitoring sustainable agricultural systems if their capacity to predict crop response and identify management

66 options is well established (e.g. Verdoodt et al., 2004). They can help to identify environmental factors limiting growth and resource use and to assess productivity and 68 profitability at various time scales (e.g. Shamudzarira and Robertson, 2002). For perennial crops much less work on production models has been carried out, probably due

70 to data limitation, relatively high research costs and the difficulties of accumulated errors in long term simulations (Zuidema et al., 2005).

The WaNulCAS model (Water Nutrients and Light Capture in Agroforestry Systems) was developed by the International Centre for Research on Agroforestry

74 (ICRAF, Indonesia) as a research tool with the major objective to synthesize existing knowledge and hypotheses on above- and below-ground resource-use by trees and crops

76 at the patch-scale (Van Noordwijk and Lusiana, 1999). Although it can undertake economic evaluations, WaNuLCAS is primarily a biophysical model that also provides a

78 great range of outputs, including soil water, transpiration, growth of trees and crops for a given environment. This model was chosen for this study since it has already been 80 parameterised for pure rubber tree stands and it included a specific module of latex production. However, it has mainly been used for long term (multi-annual) predictions of 
82 rubber tree growth in pure stand (Yahya, 2007) or in agro-forestry systems (Pinto et al., 2005). Moreover, to our knowledge, this model has not been tested for rubber tree

84 growing in drought prone area. Hence, this study had three aims: firstly, to test the possibility of using the WaNuLCAS model as an exploratory tool to analyze relationships

86 between water use, growth and latex production on an intra-annual, daily basis and in a pure stand. The second was to evaluate the relative accuracy of the simulations of soil

88 water content, tree transpiration, cambial growth and latex production. Finally, the third objective was to identify key features in the various parameterizations which may be

90 adapted to improve overall prediction quality in drought prone areas. To address these issues, simulations were compared to field measurements in a mature rubber tree stand

92 growing in the water-limited area of northeast Thailand. The period of analysis concerned seven months of full foliation and latex tapping from May to November. Four sub-

94 periods were distinguished, combining contrasted magnitudes of evaporative demand and soil water availability.

\section{MATERIALS AND METHODS}

\section{The WaNuLCAS model}

98 Version 3.2 of the WaNuLCAS model is used in this study. WaNuLCAS was developed as a collection of modules in which processes are computed at a daily time step. A short

100 description of the modules used for the simulation is given below. For more theoretical background on the modules we refer to the original model documentation of Van

102 Noordwijk and Lusiana (1999). 
The soil is divided into four layers in the vertical and four spatial zones in the

104 horizontal, and each layer is characterised by different soil properties (Figure 1). The soil hydraulic module includes pedotransfer functions (Wösten et al.1998) that are used to 106 derive the constants of the Van Genuchten (1980) equation depending on soil texture, bulk density and soil organic matter content. These constants determine the relationship 108 between soil water content, soil water potential, hydraulic conductivity and potential tree water uptake in each cell. To calculate water infiltration, the model estimates a layer-

110 specific field capacity. Two definitions of field capacity are used: (i) field capacity is the soil water content at which downward drainage would become less than a critical value of 112 conductivity (Kcrit) and would effectively stop, or (ii) field capacity is the soil water content that is in hydrostatic equilibrium with a water table at a distance defined from the

114 bottom of layer 4 . The highest of these two values in any cell is used. A saturated hydraulic conductivity (Ksat) is generated from the pedotransfer functions. The water

116 balance includes vertical and horizontal transport. It incorporates the water balance inflows and outflows described in Table 1 at daily time steps.

118 Surface run-off occurs if (i) daily rainfall exceeds daily maximum infiltration or if (ii) daily rainfall exceeds the soil potential water storage. Allocation to surface runoff or 120 infiltration in the first soil layer depends on a ratio, called SSI in this study, that is the ratio between a reference Ksat (for degraded soil) and the Ksat generated by the 122 pedotransfer function. Infiltration then follows the tipping bucket principle for wetting subsequent layers of soil, filling a cascade of soil layers up to their field capacity.

124 Tree water uptake, i.e. transpiration, is driven by evaporative demand, with the possibilities determined by tree root length density and soil water availability in the 
126 various cells to which a plant has access. A "potential transpirational demand" is estimated from LAI and $\mathrm{ET}_{0}$. Hence, the transpiration depends on a water demand 128 reduction factor or stress factor:

$$
\tau=f(\theta) \tau_{0}
$$

130 where $\tau$ is the tree water demand, $f(\theta)$ is the water demand reduction factor (where $\theta$ is the soil water content) and $\tau_{0}$ is the potential transpirational demand. The reduction

132 factor depends on the "plant water potential" which is estimated from the "soil water potential”.

134 Canopy light capture is determined by the LAI, the canopy height and the Beer's law extinction coefficient specific to rubber trees. The growth reserve pool varies with 136 the tree potential growth and the minimum stress factor regarding light, water and nitrogen. Part of the growth reserves are allocated to growth. Allometric equations are 138 used to relate tree girth to tree biomass. They allocate predicted biomass to the different tree components: below-ground and total, above-ground biomass, which in turn is

140 partitioned into roots, leaves and twigs, as well as branches. As for tree growth, part of the "tree growth reserves pool" is allocated to "daily latex production". Tapped latex 142 depends on the "fraction of latex stock" that can be tapped every day ("tapping fraction") and on existing "Brown Bast", a physiological disease that induces a reduction of latex

144 production (Paardekooper, 1989). The version of WaNuLCAS used only predicts latex production using a d/2 tapping pattern (one day of tapping - one day of rest). 
Experiment site and forestry system: The experiment site was located in Baan Sila (N15 148 16' 23.6" E103 04' 51.3", altitude = $150 \mathrm{~m}$ ) between Satuk and Khu Muang in the Buriram province of northeast Thailand. The field was a monoculture stand of RRIM600 150 rubber clones planted in 1995 (i.e. 12 years old in 2007) at a $7 \mathrm{mx} 2.5 \mathrm{~m}$ tree spacing over 5.5ha, in a deep sandy soil. Average annual rainfall in this area is $1176 \mathrm{~mm}$ (Khu Muang

152 station). The wet season lasts from May to October but intermittent dry spells often occur in June and July. Rubber trees have been tapped since June 2003. The stand was

154 modelled as a half alley system as shown in Figure 1. The 2-D unit represents a flat area $3.5 \mathrm{~m}$ wide and $1.8 \mathrm{~m}$ deep. The width was arbitrarily split into four zones of $1,1,1$ and

$1560.5 \mathrm{~m}$. Layer bottoms were set according to the main variations of soil properties in the profile, at depths of $0.25,0.5,1$ and $1.8 \mathrm{~m}$. Trees were grown in zone 1 at a density of 571

158 trees.ha $^{-1}$ (Table $\left.2(a)\right)$.

\section{Water balance}

160 Soil physical properties: the main soil properties (Hartmann et al., 2006) of each modelled layer are provided in Table 2 (b). Textures were assumed homogeneous in the

162 four zones. The soil was degraded and poorly structured. Bulk density was high in layer 2: this compaction resulted from previous cassava cultivation. Saturated hydraulic

164 conductivities (Ksat) were measured with four replications. The magnitude of the measured standard deviation suggested significant spatial variability of this parameter.

166 Soil water storage, infiltration and evaporation: WaNuLCAS requires the daily inputs of two climatic variables: rainfall and reference evapotranspiration. In Baan Sila, 
168 climatic data (air temperature, relative humidity, global radiation, wind speed and rainfall) were automatically recorded every 30 minutes with a Minimet station (Skye

170 Instruments Ltd, U.K.) in an open field located to the east of the rubber stand, 50m away from any tree. Recorded climate data were then aggregated as maximal/minimal

172 (temperature, humidity), average (wind speed) or cumulated (radiation, rainfall) daily values. Daily values of reference potential evapotranspiration were calculated using the

174 Penman-Monteith equation. Figure 2 shows the input values of climatic data. 2007 rainfall was approximately $965 \mathrm{~mm}(879 \mathrm{~mm}$ from May to November), $18 \%$ less than the

176 long-term annual average. The wet season is often interspersed with a short dry and hot period (scarce rainfall and high evaporative demand) in June and July, a feature which

178 occurred in 2007. Dry and cool conditions prevailed again from November. Climate data inputs were set equal in the four spatial zones. In the rubber stand, volumetric soil water

180 content was measured once or twice each month with a neutron probe (Troxler 3300, USA) calibrated for the experimental soil. Calibration was carried out separately for the 182 upper (0-0.2m depth) and lower (0.2-1.8m depth) layers. Measurements were made every $0.2 \mathrm{~m}$ from the ground down to a depth of $1.8 \mathrm{~m}$. Twelve access tubes of $2.0 \mathrm{~m}$ in length 184 were set up in pairs: one tube in the planting line between two trees, and the other one in the middle of the inter-row. Average measured moisture from the 12 tubes were used as 186 observational data. Initial soil water contents (i.e. in May) are given in Table 2 (b). The Kcrit value was calculated in order to get the field capacity of layer 1 equal to the soil 188 water content at a soil water potential of $-100 \mathrm{~cm}$. No water table was observed below the stand in Baan Sila. A value of $10 \mathrm{~m}$ depth was set as input for the distance from the 190 bottom of layer 4 to the supposed water table. Thus, the value of field capacity computed 
from definition (ii) was insignificant. The SSI parameter (influencing the ratio between run-off and infiltration) was calibrated in order to obtain soil water stock values during periods of high rainfall (August-September-October) similar to observed values.

Daily tree water use, i.e. transpiration, was estimated by the daily total sap flow in trunk xylem, ignoring changes in tree water storage (Isarangkool Na Ayutthaya et al., 196 2010). The measurements of xylem Sap Flow Density (SFD) on 11 trees in Baan Sila were made using the Transient Thermal Dissipation (TTD) system (Do and Rocheteau, 198 2002; Isarangkool $\mathrm{Na}$ Ayutthaya et al., 2010). A cycle of 10min heating and 20min cooling was used to measure sap flow density every 30min. The zero flux signal was 200 determined every night assuming that sap flow was negligible at the end of the night (see details in Isarangkool $\mathrm{Na}$ Ayutthaya et al., 2010). Probes were inserted into the trunks at a

202 height of $1.8 \mathrm{~m}$ above the soil. At this height, average sapwood area was estimated to be $2.04 \mathrm{dm}^{2}(\mathrm{SD}=0.47)$. Three probes were inserted into each trunk to take circumferential

204 variability into account. An average radial profile of sap flux density was also taken into account (Isarangkool $\mathrm{Na}$ Ayutthaya et al., 2010). All probes were connected to a data 206 logger (CR10X, Campbell Scientific, Leicester, U.K.). Hourly SFD was cumulated over a 24h period to calculate daily SFD and multiplied by sapwood area. Average daily total 208 flow of the representative trees was divided by the soil surface theoretically available for a tree $\left(17.5 \mathrm{~m}^{2}\right)$ in order to estimate the observed tree water uptake in $\mathrm{mm}$. Isarangkool $\mathrm{Na}$ 210 Ayutthaya et al. (2011) provide a detailed analysis of a data subset of these field measurements of water use.

Tree growth and light capture: the potential growth $\left(0.01 \mathrm{~kg} . \mathrm{m}^{-2}\right)$ was taken from WaNuLCAS default values. As inputs, the model required initial stem and canopy above- 
214 ground biomasses (Table 2 (a)). Total above-ground biomass was calculated using allometric relation between girth and weight. Constants for RRIM600 rubber trees were 216 set according to Chantuma et al. (2004):

$$
W=0.0082 * G^{2.5623}
$$
where $W$ is the above ground tree weight in $\mathrm{kg}$ and $G$ the tree girth in $\mathrm{cm}$, measured at $170 \mathrm{~cm}$ above the ground. The simulated girth increments were compared to 220 observations. The girths of 232 trees were measured using a metre rule once or twice per month in 2007 in Baan Sila. The maximum LAI (Table 2 (a)) for the year 2007 was measured by collecting fallen leaves in one square meter open boxes from November 2007 till the complete defoliation at the end of January 2008. Root biomass and root

224 length density were assumed constant for the simulation period. The average profile of root length density was taken from measurements in the site (Table 2 (b), Pierret et al., 226 unpublished report). Default model values were used for other physiological parameters.

Latex production: Observed latex production was estimated from the amount of 228 rubber sheets produced each tapping day on the whole plot, knowing the number of tapped trees and an average weight per rubber sheet of $1200 \mathrm{~g}$. The "tapping fraction" was

230 calibrated to fit the range of expected latex production at the start of tapping period in May, taking into account the fact that $30 \%$ of the trees of the plot were suffering from

232 Brown Bast and that the tapping system in the model could only be $d / 2$ instead of the observed $2 \mathrm{~d} / 3$. The used parameters in the latex module are given in Table 2 (c). Other 234 parameters have been set following WaNuLCAS default values.

\section{Evaluation of model predictions}


236 The simulation covers the period from May the $1^{\text {st }}$ to November the $30^{\text {th }}$ in 2007 . The simulation assumed no limitations due to nutrients (nitrogen or phosphorus), weeds and

238 pests. Predicted data regarding soil water content, transpiration, girth increment and latex production were compared to field measurements. The analysis used determination 240 coefficients $\left(R^{2}\right)$ and relative root mean square errors $R M S E_{\text {rell }}$ :

$$
R M S E_{r e l}=\frac{100}{\bar{O}} \sqrt{\frac{\sum_{i=1}^{n}\left(P_{i}-O_{i}\right)^{2}}{n}}
$$
where $O$ and $P$ represent observed and predicted values, respectively, and $\bar{O}$ represents the observed value average. The number of observations is $n . R^{2}$ and $R M S E_{\text {rel }}$

244 for transpiration estimates were compared over the seven months of study and for the four climatic sub-periods (Figure 2): one combining high evaporative demand and low

246 soil water constraint (May); two periods combining high evaporative demand and high soil water constraint (June-July and November); and one combining low evaporative

248 demand and low soil water constraint (August-September-October).

\section{RESULTS}

\section{Water balance}

Soil water content: Observations ranged from 5 to $25 \%$ (Figure 3). Soil moisture 252 decreased in each layer during the short dry period of June and July. Model results followed the same pattern but they were often overestimated, particularly in layer $3 . R^{2}$ of

254 layers $1,2,3$ and 4 were $0.218,0.307,0.277$ and 0.496 , respectively, and $R M S E_{\text {rel }}$ values were $34.7,39.8,68.7$ and $22.3 \%$, respectively. For the total profile, $R^{2}$ and $R M S E_{\text {rel }}$ values 
were 0.461 and $34.9 \%$, respectively.

Tree transpiration: Measured values ranged from 0.3 to $2.3 \mathrm{~mm} \cdot \mathrm{d}^{-1}$ (Figure 4).

258 Transpiration dramatically decreased during the intermittent droughts in June and July. It also progressively decreased in November at the beginning of the long dry period.

260 Predicted and observed values were in the same range during periods without soil water constraint and with low or moderate evaporative demand $\left(\mathrm{ET}_{0}<2 \mathrm{~mm} \cdot \mathrm{d}^{-1}\right.$, September-

262 October). In contrast, model-predicted values were significantly overestimated in periods of high evaporative demand $\left(\mathrm{ET}_{0}>2 \mathrm{~mm} \cdot \mathrm{d}^{-1}\right.$ : start of May, June and July, November).

264 Moreover, the dramatic reduction of transpiration in June and July due to soil drought was not simulated. Finally, $R^{2}$ and $R M S E_{\text {rel }}$ values equalled 0.104 and $94 \%$, respectively.

\section{Tree growth}

Observed tree girth increased at the beginning of the rainy season (May-June) and then 268 stopped and decreased in July in accordance with the decline in transpiration (Figure 5). Girth increased again from August to October. The total increment reached $1.3 \mathrm{~cm}$ over

270 the seven-month period. The model significantly overestimated girth increment. Final $R^{2}$ and $R M S E_{\text {rel }}$ values were 0.916 and $208 \%$, respectively.

\section{Latex prediction}

Observed values ranged from 1.3 and $19 \mathrm{~kg} \cdot \mathrm{ha}^{-1} \cdot \mathrm{d}^{-1}$ and the pattern was not correlated to

274 variation in transpiration (Figure 6). As for growth, the model did not predict any reduction due to water stress and the latex production is largely overestimated. Total

276 predicted production $\left(2888 \mathrm{~kg} \cdot \mathrm{ha}^{-1}\right)$ was twice the measured production $\left(1416 \mathrm{~kg} \cdot \mathrm{ha}^{-1}\right)$ 
over the simulated period. Finally, $R^{2}$ and $R M S E_{\text {rel }}$ values were 0.423 and $169 \%$, 278 respectively.

\section{DISCUSSION}

280 WaNuLCAS model as an exploratory tool

The test of the possibility of using WaNuLCAS model as an exploratory tool for a pure

282 rubber tree stands appeared to be successful. It simulated daily changes in transpiration, girth increment and latex production within plausible ranges (Silpi et al., 2006;

284 Pakianathan et al., 1989; Watson, 1989). In addition, the model runs were easily implemented and several shortcuts were available to test the schematic inputs of rainfall,

$286 \mathrm{ET}_{0}$, etc.

\section{Relative accuracy of simulations}

288 With the current model version and parameters, results showed large inaccuracies for certain model predictions: soil water content $\left(R^{2}=0.461, R M S E_{\text {rel }}=34.9 \%\right)$, tree 290 transpiration $\left(R^{2}=0.104, R M S E_{\mathrm{rel}}=94 \%\right)$, tree girth increment $\left(R^{2}=0.916, R M S E_{\mathrm{rel}}=\right.$ $208.4 \%)$ and latex production $\left(R^{2}=0.423, R M S E_{\text {rel }}=169.5 \%\right)$. However, as the water

292 shortage in June and July was not predicted by the model, the significant overestimations in girth increment and latex production appear logical and can not be discussed in further

294 depth. Hence, the focus of this investigation is foremost on the soil water balance and tree water use. Model estimations of tree transpiration were correct in conditions without soil

296 and atmospheric droughts. Major inaccuracies resulted from (i) the non-prediction of soil water shortage and (ii) the overestimation of tree transpiration under high evaporative 
demand and non-limiting conditions of soil water.

The soil water shortage was not predicted because the soil water content was

300 overestimated in all layers except in the lowest one. In WaNuLCAS, as in all reservoir models, infiltration water fills each layer of soil until their field capacity is reached and

302 the excess moisture wets the subsequent soil layer. The speed of the process depends on the infiltration rate. When the deepest layer reaches its field capacity, excess water is then

304 lost by deep drainage. A small error in predicting soil water content in upper layers may thus be amplified in deeper layers. Bias in predicting soil water content can come from 306 errors in predicting (i) the layers field capacity and (ii) the infiltration rate of each layer, particularly in the upper-most layer which determines the infiltration/runoff ratio. Aware 308 of these points, measured Ksat and a calibrated ratio between infiltration and runoff (SSI) were used. The default values of Ksat and SSI provided by the pedotransfer functions of 310 WaNuLCAS were even higher than our estimated values and induced even greater overestimates of soil water content. Other authors reported inadequacies of the 312 pedotransfer functions and predicted infiltration by WaNuLCAS for tropical soils (Hodnett and Tomasella, 2002; Walker et al., 2007; Pansak et al., 2010). To explain the

314 overestimate of soil water content, despite the use of measured Ksat and calibrated SSI values, several hypotheses are proposed. Firstly, measured Ksat is still overestimated, 316 particularly in the upper layer. This is possible because the variability between field measurements of Ksat was very large (Table 2 (b)). Moreover, significant surface 318 flooding and run-off were observed for each important rainfall event. Secondly, the infiltration of water is not homogeneous between the tree row and in the inter-row space.

320 Surface flooding and run-off was of greater importance in the inter-row spaces which are 
at a lower level than the tree rows. In addition, preferential vertical flow may occur in the inter-row spaces, which may induce deep, localised drainage.

In addition, the model overestimated maximum transpiration because it simulated

324 tree transpiration that follows the evaporative demand without any stomatal regulation due to atmospheric conditions. The only water-regulation included in the model

326 originates from soil water shortage, similar to the majority of models. However, observed data showed that effective regulation of transpiration occurred above $\mathrm{ET}_{0}$ equal to $2.0 \mathrm{~mm}$

328 (Fig. 4). This is, however, a very recent result for rubber trees (Isarangkool Na Ayyuthaya et al., 2011), which may differ according to the clone (here RRIM 600). The 330 regulation of transpiration at high evaporative demand, whatever the soil water availability, has been quoted for several species and environments (David et al., 2004;

332 Bovard et al., 2005; Oguntunde et al., 2007; Bush et al., 2008). Moreover, the overestimate of transpiration in the simulation should further decrease the soil water

334 reserve, which emphasizes the current overestimation of soil water content by the model. The current version of the WaNuLCAS model has, however, already predicted correct 336 values of rubber tree growth and production over long periods in other regions (Pinto et al., 2005; Yahya, 2007). We assume that these results likely correspond to environmental 338 conditions without high evaporative demand.

\section{Key points of parameterization and improvement}

340 Under the conditions of degraded soil and high evaporative demand investigated, the key point of parameterization and improvement are the soil water balance and the regulation

342 of tree transpiration under high evaporative demand. It is likely that the ability to separate 
soil properties between horizontal zones in the model will facilitate the improvement of

344 the simulated soil water balance. This is particularly the case in rubber tree plantations, where several years of different soil-, weed- and litter-management practices between

346 tree row and inter-row spaces may influence the topography and soil properties related to soil water infiltration and balance. Secondly, the regulation of transpiration as a function

348 of evaporative demand requires the introduction of a new equation or reduction factor. The transpiration model in Granier et al. (2000) provides an example of a multiple 350 regulation of canopy conductance where atmospheric drought is taken into account whatever the soil water conditions.

\section{CONCLUSIONS}

In conclusion, the WaNuLCAS model appears to be a useful exploratory tool for the

354 simulation of water use, growth and latex production in a pure stand of rubber tree on a daily basis. Results do, however, show that under the conditions of degraded soil and 356 high evaporative demand investigated, the modules of soil water balance and tree transpiration require particular parameterizations and improvement in order to more 358 accurately represent these processes.

Acknowledgments. The authors thank all French and Thai counterparts from the

362 Institute of Research for Development (IRD), the Khon Kaen University and the Land Development Department. We particularly thank the Land Development Department of 
364 Bangkok and Dr. Darunee Chairod for the assistance in neutron probe measurements. We are grateful to Dr Henri Robain for his support as coordinator of the agreement program

366 between IRD and the Rubber French Institute. Were also are very grateful to Mr. Chaipat Sirichaiboonwat who welcomed us so kindly in his rubber tree plantation. Finally, we 368 sincerely thank Ms Ni'matul Khasanah (ICRAF, Indonesia), Dr Fiona Tummon (CNRS, France) and Dr Erwan Motte (STARLAB, Spain) for their kind assistance in achieving 370 this work.

Funding. This Thai-French research was funded by the French Institute of 372 Research for Development (IRD), the Rubber French Institute (IFC) and by Michelin/Socfinco/SIPH Plantations companies.

\section{REFERENCES}

376 Bovard, B.D., Curtis, P.S., Vogel, C.S., Su, H.-B. \& Schmid, H.P. (2005). Environmental controls on sap flow in a northern hardwood forest. Tree Physiology 25:31-38.

378 Bush, S.E., Pataki, D.E., Hultine, K.R., West, A.G., Sperry, J.S. \& Ehleringer, J.R. (2008). Wood anatomy constrains stomatal response to atmospheric vapor pressure deficit in irrigated, urban trees. Oecologia 156:13-20.

Chandrashekar, T.R., Nazeer, M.A., Marattukulam, J.G., Prakash, J.P., Annamalainathan, K. \& Thomas, J. (1998). An analysis of growth and drought tolerance in rubber during the immature phase in dry subhumid climate. Experimental Agriculture 34:287-300. 
Chantuma, A., Chantuma, P., Rhutherman, S., Tsongpanich, P., Bunnuam, W., Kongsilp,

J. \& Kesawapitak, P. (2004). Carbon sequestration: direct rubber biomass measurement and visual wood weight, IRRDB Meeting, Kunming, China.

David, T.S., Ferreira, M.I., Cohen, S., Pereira, J.S. \& David, J.S. (2004). Constrains on transpiration from an evergreen oak tree in southern Portugal. Agricultural and Forest Meteorology 122:193-205.

Do, F. \& Rocheteau, A. (2002). Influence of natural temperature gradients on measurements of xylem sap flow with thermal dissipation probes. 2. Advantages and calibration of a non-continuous heating system. Tree Physiology 22:649-654.

394 Granier, A., Loustau, D. \& Breda, N. (2000). A generic model of forest canopy conductance dependent on climate, soil water availability and leaf area index. Annals of Forest Science 57:755-765.

Hartmann, C., Lesturgez, G., Do, F., Maeght, JL., Isarangkool Na Ayutthaya, S. \& Nandris, D. (2006). Rubber tree Trunk Phloem Necrosis in North-East Thailand: 1-Investigations on soil heterogeneities and disease distribution, IRRDB Meeting, Ho Chi Minh City, Vietnam, 13-16 November 2006.

Hodnett, M.G. \& Tomasella, J. (2002). Marked differences between van Genuchten soil 402 water-retentions parameters for temperate and tropical soils: a new waterretention pedotransfer function developed for tropical soils. Geoderma 108:155180.

Isarangkool Na Ayutthaya, S., Do, F.C., Pannengpetch, K., Junjittakarn, J., Maeght, J.L., 406 Rocheteau, A. \& Cochard, H. (2010). Transient thermal dissipation method of 
xylem sap flow measurement: multi-species calibration and field evaluation. Tree Physiology 30:139-148.

Isarangkool Na Ayutthaya, S., Do, F.C., Pannengpetch, K., Junjittakarn, J., Maeght, J.L., Rocheteau, A. \& Cochard, H. (2011). Water loss regulation in mature Hevea brasiliensis: effects of intermittent drought in the rainy season and hydraulic regulation. Tree Physiology (doi:10.1093/treephys/tpr058, advance access published July 11).

414 Oguntunde, P.G., Van de Giesen, N. \& Savenije, H.H.G. (2007). Measurement and modeling of transpiration of a rain-fed citrus orchard under subhumid tropical conditions. Agricultural Water Management 87:200-208.

Paardekooper, E.C. (1989). Exploitation of the rubber tree. In Rubber, 349-414. (Eds C.C. Webster and W.J. Baulkwill). Tropical Agriculture Series, Longman Scientific and Technical. Singapore.

420 Pakianathan, S.W., Haridas, G. \& d'Auzac J. (1989). Water relations and latex flow. In Physiology of rubber tree latex, 233-256 (Eds J. d'Auzac, J.L. Jacob and H. Chrestin). CRC Press, Inc, Florida.

Pansak, W., Hilger, T., Lusiana, B., Kongkaew, T., Marohn, C. \& Cadish, G. (2010). Assessing soil conservation strategies for upland cropping in Northeast Thailand with the WaNuLCAS model. Agroforestry Systems 79:123-144.

426 Pinto, L.F.G., Bernardes, M.S., Van Noordwijk, M., Pereira, A.R., Luisiana, B. \& Mulia, R. (2005). Simulation of agroforestry systems with sugarcane in Piracicaba, 
Rao, G.G., Rao, P.S., Rajagopal, R., Devakumar, A.S., Vijayakumar, A.S. \& Sethuraj, M.R. (1990). Influence of soil, plant and meteorological factors on water relations and yield in Hevea brasiliensis. International Journal of Biometeorology 34:175180.

Rao, P.S., Saraswathyamma, C.K. \& Sethuraj, M.R. (1998). Studies on the relationship between yield and meteorological parameters of para rubber tree (Hevea brasiliensis). Agricultural and Forest Meteorology 90:235-245.

436 Shamudzarira, Z. \& Robertson, M.J. (2002). Simulating response of maize to nitrogen fertilizer in semi-arid Zimbabwe. Experimental Agriculture 38:79-96.

438 Silpi, U., Thaler, P., Kasemsap, P., Lacointe, A., Chantima, A., Adam, B., Gohet, E., Thanisawanyangkura S., \& Ameglio, T. (2006). Effects of tapping activity on the dynamics of radial growth of Hevea brasiliensis trees. Tree Physiology 26:15791587.

442 Van Genuchten, M.T. (1980). A closed-form equation predicting the hydraulic conductivity of unsaturated soils. Soil Science Society of America Journal 44:892898.

Van Noordwijk, M. \& Lusiana, B. (1999). WaNuLCAS, a model of water, nutrient and light capture in agroforestry systems. Agroforestry Systems 43: 217-242.

Verdoodt, A., Van Ranst, E. \& Ye, L. (2004). Daily simulation of potential dry matter 448 production of annual field crops in tropical environments. Agronomy Journal 
96:1739-1753.

450 Walcker, A.P., Mutuo, P.K., Van Noordwijk, M., Albrecht, A. \& Cadish, G. (2007). Modelling of planted legume fallows in Western Kenya using WaNuLCAS. (I) Model calibration and validation. Agroforestry Systems 70:197-209.

Watson, G.A. (1989). Climate and soil. In Rubber, 125-163 (Eds C.C. Webster and W.J. Baulkwill). Tropical Agriculture Series, Longman Scientific and Technical. Singapore.

456 Wösten, J.H.M., Lilly, A., Nemes, A. \& Le Bas, C. (1998). Using existing soil data to derive hydraulic parameters for simulation models in environmental studies and in land use planning. Report 156, SC-DLO, Wageningen (the Netherlands), 106 pp.

Yahya, A.K. (2007). Estimating growth (girth), yield and aboveground biomass of Hevea 460 brasiliensis: Validation of the WaNuLCAS model. Journal of Rubber Research $3: 183-192$.

462 Zuidema, P.A., Leffelaar, P.A., Gerritsma, W., Mommer, L. \& Anten, N.P.R. (2005). A physiological production model for cocoa (Theobroma cacao): model presentation, validation and application. Agricultural Systems 84:195-225. 
Boithias, Do, Isarangkool Na Ayutthaya, Junjittakarn, Siltecho, and Hammecker

466

Table 1. In- and outflows elements of WaNuLCAS water balance

\begin{tabular}{ll}
\hline In & Out \\
\hline Initial soil water content for each cell & Final soil water content for all zones and layers \\
Allocated rainfall to infiltration & Allocated rainfall to surface run-off \\
& Drainage from bottom of soil profile \\
& Soil evaporation \\
& Evaporation of canopy intercepted water \\
& Transpiration by tree \\
\hline
\end{tabular}

Table 2. Inputs set in WaNuLCAS for simulation initialisation.

\begin{tabular}{|c|c|c|c|c|c|c|c|}
\hline \multicolumn{8}{|c|}{ (a) Agroforestry system and tree dimensions } \\
\hline \multicolumn{4}{|c|}{ Tree density $\left(\right.$ tree $\left.\mathrm{ha}^{-1}\right)$} & 571 & \multicolumn{2}{|c|}{ Initial canopy biomass $\left(\mathrm{kg} \cdot\right.$ tree $\left.^{-1}\right)$} & 51.1 \\
\hline \multicolumn{4}{|c|}{ Initial stem biomass $\left(\mathrm{kg}\right.$.tre $\left.\mathrm{e}^{-1}\right)$} & 97.7 & \multicolumn{2}{|c|}{ Canopy height $(\mathrm{m})$} & 12 \\
\hline \multicolumn{4}{|c|}{ Stem height $(\mathrm{m})$} & 3 & \multicolumn{2}{|l|}{ Canopy max. width (m) } & 3.5 \\
\hline \multicolumn{4}{|c|}{ Max. Leaf Area Index } & 3.89 & & & \\
\hline \multicolumn{8}{|c|}{ (b) Soil physical inputs and initial root distribution in the four zones } \\
\hline & $\begin{array}{l}\text { Clay } \\
(\%)\end{array}$ & $\begin{array}{l}\text { Silt } \\
(\%)\end{array}$ & $\begin{array}{l}\text { Organic } \\
\text { matter } \\
(\%)\end{array}$ & $\begin{array}{l}\text { Bulk } \\
\text { density } \\
\left(\text { g.cm }{ }^{-3}\right)\end{array}$ & $\begin{array}{l}\text { Ksat } \\
\left(\mathrm{cm} \cdot \mathrm{d}^{-1}\right)\end{array}$ & $\begin{array}{l}\text { Initial soil } \\
\text { water content } \\
\left(\mathrm{cm}^{3} .100 \mathrm{~cm}^{-3}\right)\end{array}$ & $\begin{array}{l}\text { Initial tree } \\
\text { roots } \\
\text { distribution } \\
\left(\mathrm{cm} \cdot \mathrm{cm}^{-3}\right)\end{array}$ \\
\hline Layer 1 & 9.9 & 24.2 & 0.78 & 1.5 & $(\mathrm{SD}=20.0)$ & 20.76 & 2.5 \\
\hline Layer 2 & 13.3 & 24.3 & 0.32 & 1.65 & $(\mathrm{SD}=40.4)$ & 17.63 & 2 \\
\hline Layer 3 & 20.2 & 22.7 & 0.34 & 1.5 & $(\mathrm{SD}=23.3)$ & 14.90 & 1.5 \\
\hline Layer 4 & 20.2 & 23.6 & 0.34 & 1.5 & $(\mathrm{SD}=1.0)$ & 11.03 & 1 \\
\hline \multicolumn{8}{|c|}{ (c) Latex production } \\
\hline \multicolumn{4}{|c|}{ Influence by Brown Bast } & Yes & \multicolumn{2}{|l|}{ Tapped girth fraction } & 0.3 \\
\hline \multicolumn{4}{|c|}{ Tappable height (cm) } & 150 & \multicolumn{2}{|l|}{ Tapping slice $(\mathrm{cm})$} & 0.29 \\
\hline \multicolumn{4}{|c|}{ Min. stem girth for tapping $(\mathrm{cm})$} & 30 & \multicolumn{2}{|c|}{ Tapping fract. in tapping period } & 0.06 \\
\hline
\end{tabular}


Boithias, Do, Isarangkool Na Ayutthaya, Junjittakarn, Siltecho, and Hammecker

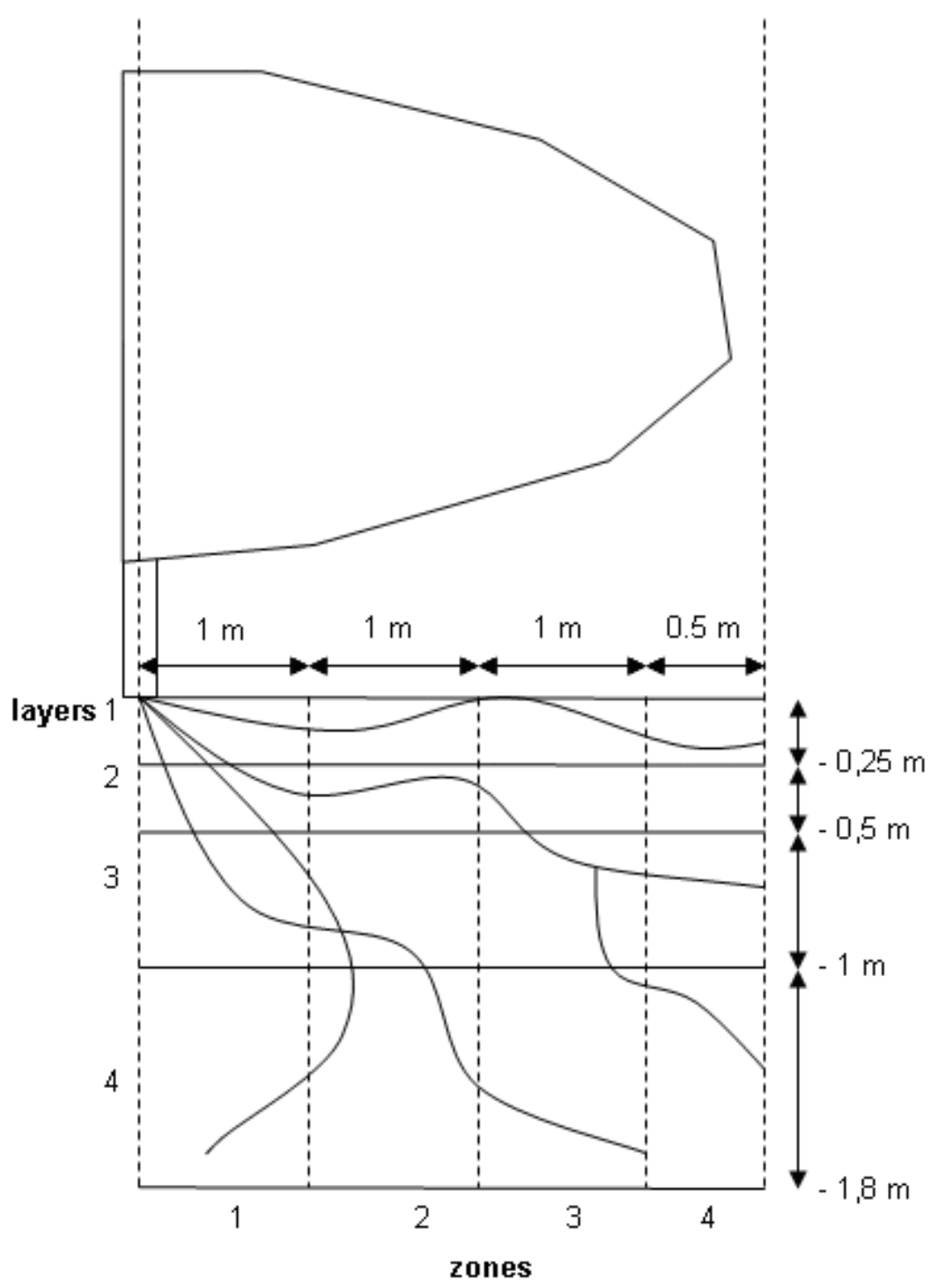

Figure 1. General layout of soil layers and spatial zones in the WaNuLCAS model. Modelled trees were planted in Zone 1. Adapted from Van Noordwijk and Lusiana (1999). 


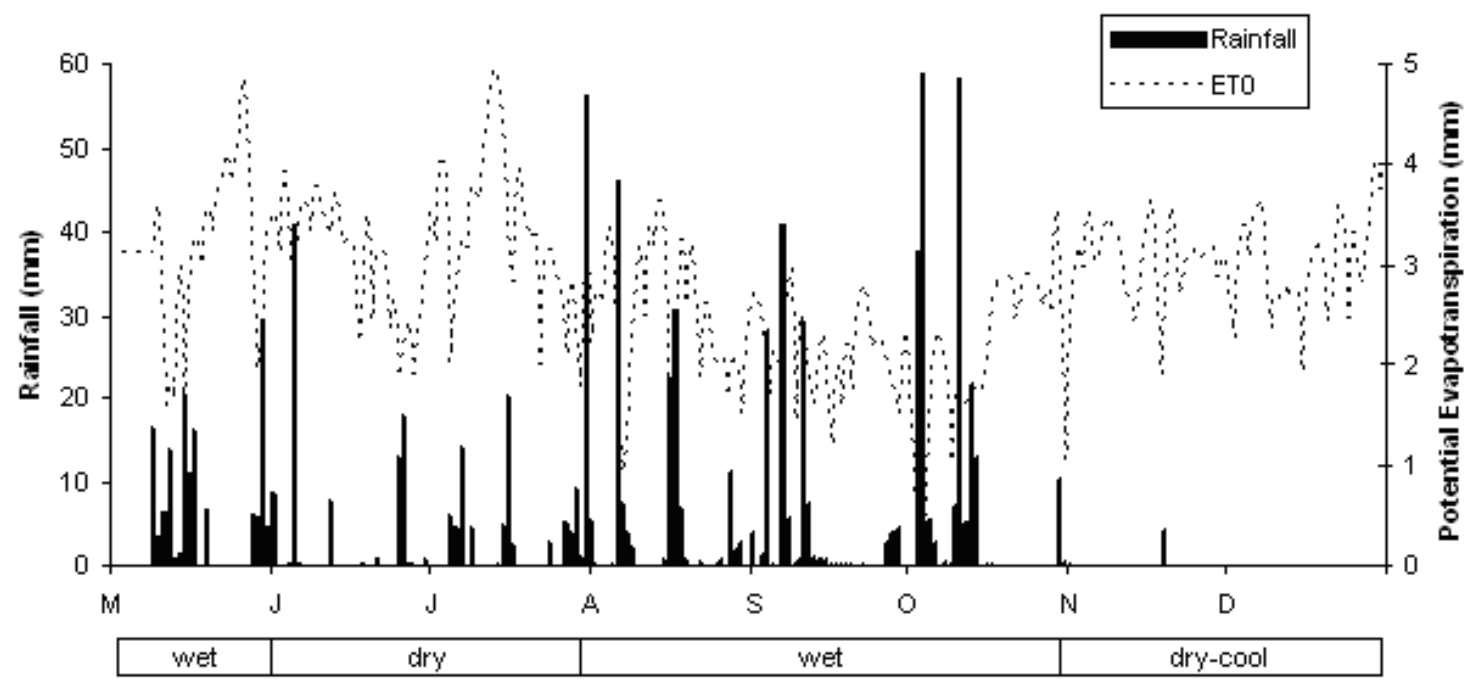



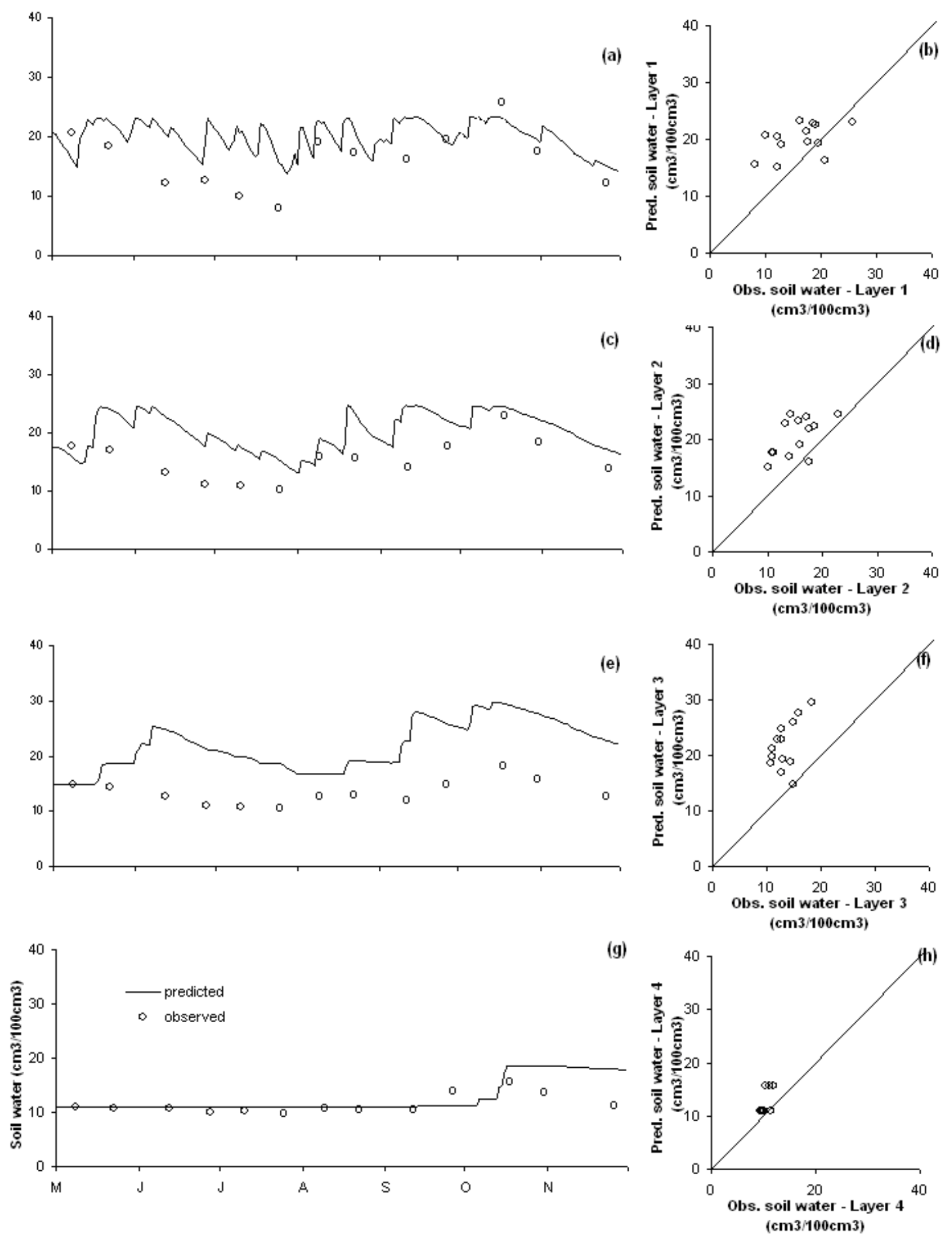

Figure 3. Observed and predicted soil water content: (a) and (b) Layer 1; (c) and (d) Layer 2; (e) and (f) Layer 3; (g) and (h) Layer 4. Diagonal lines indicate the 1-1 lines. 

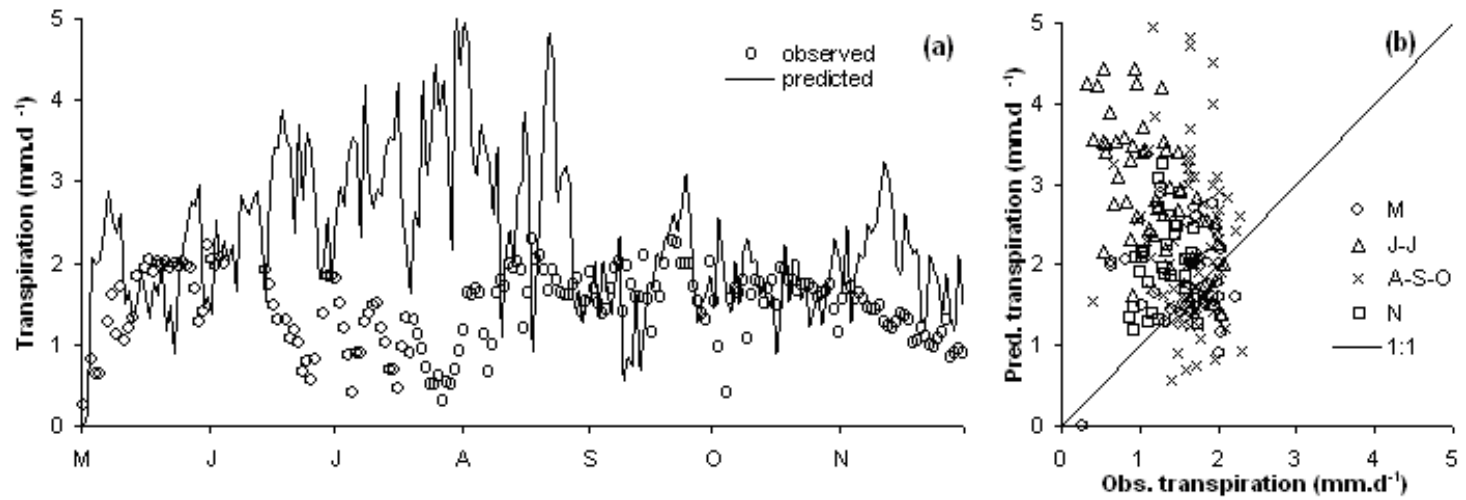

Figure 4. (a) Observed and predicted tree transpiration; (b) Predicted vs. observed. Diagonal line indicates 482 the 1-1 line.
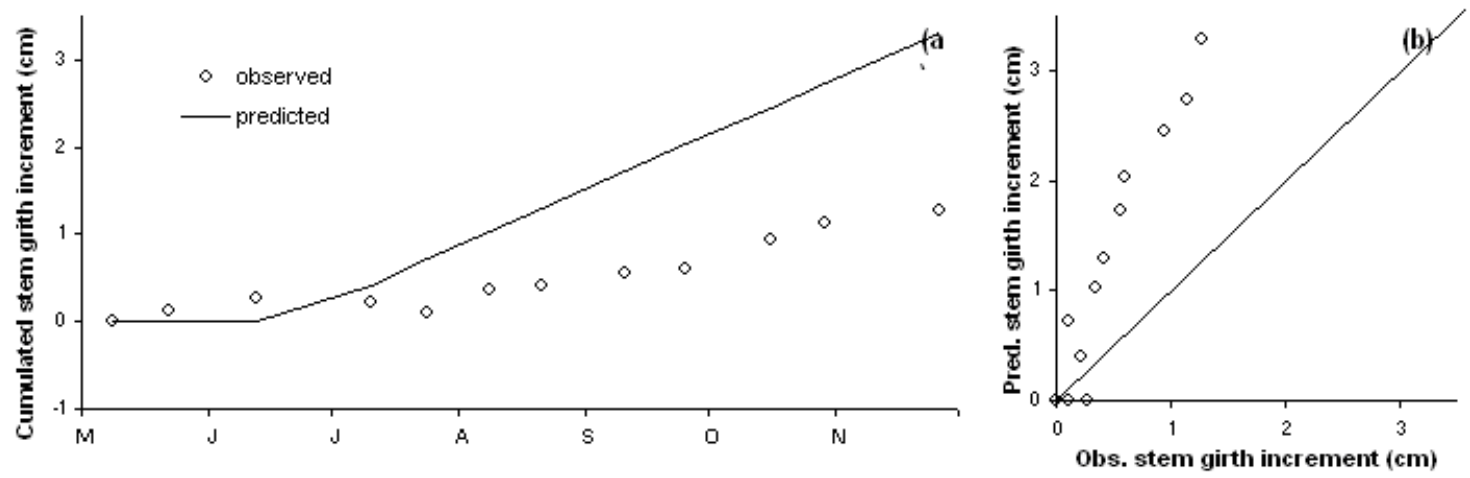

484 Figure 5. (a) Observed and predicted cumulated stem girth increment; (b) Predicted vs. observed. Diagonal line indicates the 1-1 line.

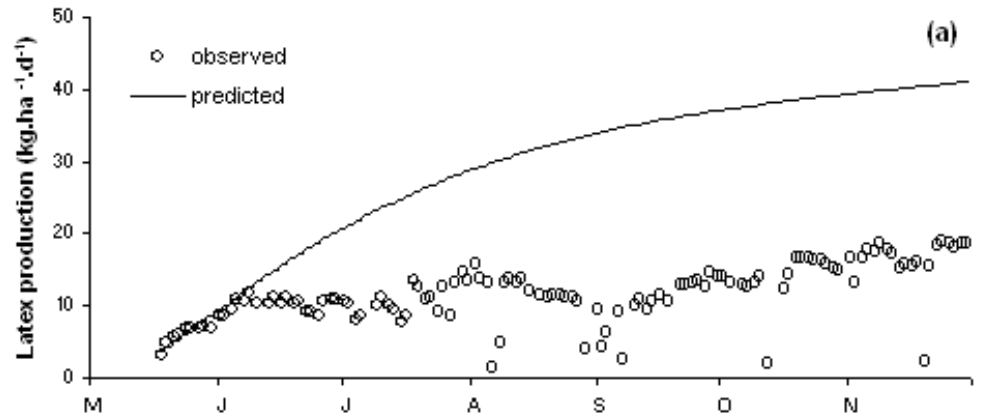

Figure 6. (a) Observed and predicted latex production; (b) Predicted vs. observed. Diagonal line indicates

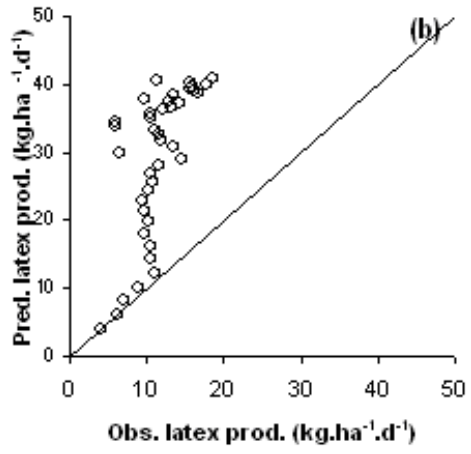

obs. latex prod. $\left(\mathrm{kg}_{\mathrm{h}} \mathrm{ha}^{-1} \cdot \mathrm{d}^{-1}\right)$ the 1-1 line. 